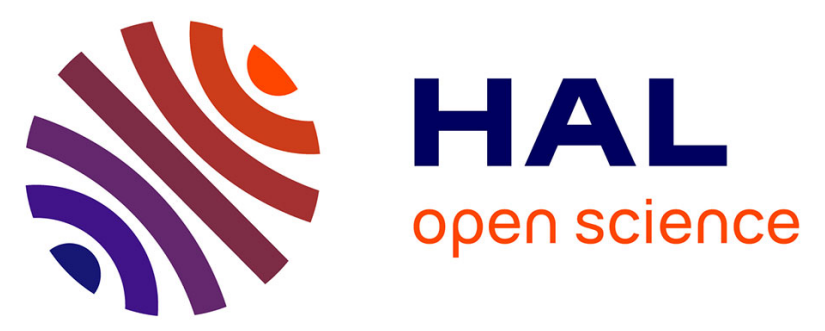

\title{
Snapshot of a Chelation-Assisted C-H/Alkyne Coupling: A Ruthenium Complex Caught in the Act of C-C Bond Formation
}

\author{
Laure Benhamou, Vincent César, Noël Lugan, Guy Lavigne
}

\section{To cite this version:}

Laure Benhamou, Vincent César, Noël Lugan, Guy Lavigne. Snapshot of a Chelation-Assisted C-H/Alkyne Coupling: A Ruthenium Complex Caught in the Act of C-C Bond Formation. Organometallics, 2007, 26 (18), pp.4673-4676. 10.1021/om7005003 . hal-02462875

\section{HAL Id: hal-02462875}

\section{https://hal-normandie-univ.archives-ouvertes.fr/hal-02462875}

Submitted on 31 Jan 2020

HAL is a multi-disciplinary open access archive for the deposit and dissemination of scientific research documents, whether they are published or not. The documents may come from teaching and research institutions in France or abroad, or from public or private research centers.
L'archive ouverte pluridisciplinaire HAL, est destinée au dépôt et à la diffusion de documents scientifiques de niveau recherche, publiés ou non, émanant des établissements d'enseignement et de recherche français ou étrangers, des laboratoires publics ou privés. 


\title{
Snapshot of a Chelation-Assisted C-H/Alkyne Coupling: A Ruthenium Complex Caught in the Act of $\mathrm{C}-\mathrm{C}$ Bond Formation
}

\author{
Laure Benhamou, Vincent César, Noël Lugan, and Guy Lavigne* \\ Laboratoire de Chimie de Coordination du CNRS, 205 Route de Narbonne, 31077 Toulouse Cedex, France
}

Received May 21, 2007

\begin{abstract}
The complex $\mathrm{Ru}(\mathrm{CO})_{2}\left(\mathrm{PPh}_{3}\right)_{3}(\mathbf{1})$ reacts with $o$-(diphenylphosphanyl)benzaldehyde within 2 min at 20 ${ }^{\circ} \mathrm{C}$ to give the hydrido acyl complex $\mathrm{Ru}(\mathrm{H})\left\{\mathrm{P}\left(\mathrm{C}_{6} \mathrm{H}_{5}\right)_{2}\left(\mathrm{C}_{6} \mathrm{H}_{4}\right) \mathrm{C}(\mathrm{O})\right\}(\mathrm{CO})_{2}\left(\mathrm{PPh}_{3}\right)(2)$ via selective activation of the $\mathrm{C}-\mathrm{H}$ bond of the aldehyde function. Further addition of diphenylacetylene $\left(110{ }^{\circ} \mathrm{C}, 3 \mathrm{~h}\right)$ affords

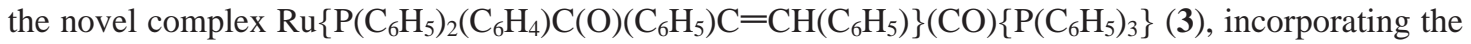
newly assembled $o$-(diphenylphosphanyl)phenyl $(E)$-stilbenyl ketone ligand. The $\alpha, \beta$-unsaturated ketone moiety of the latter is bound to the metal in an $\eta^{4}$ coordination mode involving both a side-on coordination of the carbonyl group and a more classical $\eta^{2}$ linkage of the olefinic bond. Both complexes were fully characterized by spectroscopic methods and by X-ray diffraction. The whole reaction sequence provides a valuable experimental model for the chelation-assisted hydroacylation of an alkyne with a tethered aldehyde.
\end{abstract}

\section{Introduction}

The development of transition metal catalysts for the functionalization of a broad range of substrates via $\mathrm{C}-\mathrm{H}$ bond activation has been recognized as one of the major challenges in modern chemistry. ${ }^{1,2}$

A benchmark example illustrating the use of directing groups in transition-metal-catalyzed $\mathrm{C}-\mathrm{H} /$ olefin coupling can be found in the early pioneering work of Suggs ${ }^{3}$ on the rhodium-catalyzed hydroacylation of ethylene. In that case, a chelation auxiliary, 2-amino-3-methylpyridine, was introduced to convert reversibly the aldehyde into an aldimine, thus being directly suitable for a chelating interaction of type (a) with the metal (see graphic below). ${ }^{3}$ An elegant modern illustration of this concept can be found in the $\mathrm{Ru}$-catalyzed coupling of aldimines with arylboronates for the production of aromatic ketones. ${ }^{4} \mathrm{~A}$ related chelation-assistance strategy (interaction of type (b)) was extensively developed by Murai and Kakiuchi ${ }^{2,5}$ beyond their original discovery of the Ru-catalyzed ortho-functionalization of acetophenone. ${ }^{5}$

In the latter case, the concept was extended to olefinic $\mathrm{C}-\mathrm{H}$ bond activation, ${ }^{6}$ applied to a variety of directing groups ${ }^{1,2}$ as well as to other metals. ${ }^{7}$ Although it has been demonstrated that a few selective additions to $\mathrm{Ir}$ of $\mathrm{C}-\mathrm{H}$ bonds ortho to

* Corresponding author. E-mail: Guy.Lavigne@1cc-toulouse.fr.

(1) (a) Dyker, G. Handbook of C-H Transformations; Wiley-VCH: Weinheim, 2005. (b) Kakiuchi, F.; Chatani, N. Adv. Synth. Catal. 2003 345, 1077, and references therein. (c) Ritleng, V.; Sirlin, C.; Pfeffer, M Chem. Rev. 2002, 102, 1731. (d) Dyker, G. Angew. Chem., Int. Ed. 1999, 38, 1698. (e) Guari, Y.; Sabo-Etienne, S.; Chaudret, B. Eur. J. Inorg. Chem. 1999, 1047.

(2) (a) Kakiuchi, F.; Murai, S. Acc. Chem. Res. 2002, 35, 826. (b) Murai, S.; Kakiuchi, F.; Sekine, S.; Tanaka, Y.; Kamatani, A.; Sonoda, M.; Chatani, N. Pure Appl. Chem. 1994, 66, 1527. (c) Kakiuchi, F.; Murai, S. In Topics in Organometallic Chemistry; Murai, S., Ed.; Springer: Berlin 1999; Vol. 3, p 47. (d) Jia, C.; Kitamura, T.; Fujiwara, Y. Acc. Chem. Res. 2001, 34, 633. (e) Horino, Y. Angew. Chem., Int. Ed. 2007, 46, 2144.

(3) Suggs, J. W. J. Am. Chem. Soc. 1979, 101, 489

(4) Park, Y. J.; Jo, E.-A.; Jun, C. H. Chem. Commun. 2005, 1185

(5) Murai, S.; Kakiuchi, F.; Sekine, S.; Tanaka, Y.; Katamani, A.; Sonoda, M.; Chatani, N. Nature 1993, 366, 529.

(6) (a) Trost, B. M.; Imi, K.; Davies, I. W. J. Am. Chem. Soc. 1995 , 117, 5371. (b) Kakiuchi, F.; Tanaka, Y.; Sato, T.; Chatani, N.; Murai, S. Chem. Lett. 1995, 79.

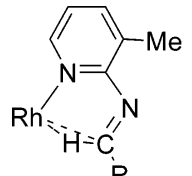

(a)

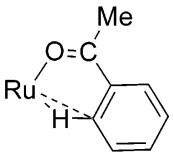

(b) coordinating groups are not chelation-assisted, ${ }^{8}$ the concept is now currently generalized to a growing number of important new types of coupling reactions., ${ }^{1,2,4}$ Quite surprisingly, however, whereas theoretical investigations have offered reliable models for Murai-type $\mathrm{CC}$ bond forming steps under $\mathrm{C}-\mathrm{H}$ activation, ${ }^{10}$ there are only rare examples of effective isolation of intermediate complexes involved in any of the above types of substrate transformations. ${ }^{11}$

Keeping in mind our previous findings in collaboration with Kalck on the ruthenium-catalyzed hydroesterification of ethylene with methyl formate ${ }^{12}$ and the more recent report by Chang and co-workers ${ }^{13}$ that a pyridine-functionalized formate undergoes a chelation-assisted $\mathrm{C}-\mathrm{H}$ functionalization with an elusive ruthenium catalyst generated in situ from $\mathrm{Ru}_{3}(\mathrm{CO})_{12}$, we became

(7) (a) Lenges, C. P.; Brookhart, M. J. Am. Chem. Soc. 1999, 121, 6616. (b) Wiedemann, S. H.; Lewis, J. C.; Ellman, J. A.; Bergman, R. G. J. Am. Chem. Soc. 2006, 128, 2452. (c) Thu, H.-Y.; Yu, W.-Y.; Che, C. M. J. Am. Chem. Soc. 2006, 128, 9048.

(8) Zhang, X.; Kanzelberger, M.; Emge, T. J.; Goldman, A. S. J. Am Chem. Soc. 2004, 126, 13192.

(9) (a) Colby, D. A.; Bergman, R. G.; Ellman, J. A. J. Am. Chem. Soc 2006, 128, 5604. (b) Ackerman, L.; Althammer, A.; Born, R. Angew. Chem. Int. Ed. 2006, 45, 2619. (c) Kakiuchi, F.; Matsuura, Y.; Kan, S.; Chatani, N. J. Am. Chem. Soc. 2005, 127, 5936. (d) Kakiuchi, F.; Kan, S.; Igi, K.; Chatani, N.; Murai, S. J. Am. Chem. Soc. 2003, 125, 1698. (e) Kakiuchi, F.; Usui, M.; Ueno, S.; Chatani, N.; Murai, S. J. Am. Chem. Soc. 2004 126, 2706. (f) Jun, C.-H.; Lee, H. J. Am. Chem. Soc. 1999, 121, 880. (g) Martinez, R.; Chevalier, R.; Darses, S.; Genet, J. P. Angew. Chem., Int. Ed. 2006, 45, 8232, and references therein.

(10) (a) Matsubara, T.; Koga, N.; Musaev, D. G.; Morokuma, K. J. Am. Chem. Soc. 1998, 120, 12692. (b) Matsubara, T.; Koga, N.; Musaev, D. G.; Morokuma, K. Organometallics 2000, 19, 2318.

(11) (a) Drouin, S. D.; Amoroso, D.; Yap, G. P. A.; Fogg, D. E. Organometallics 2002, 21, 1042. (b) Jazzar, R. F. R.; Varrone, M.; Burrows, A. D.; Macgregor, S. A.; Mahon, M. F.; Whittlesey, M. K. Inorg. Chim. Acta 2006, 359, 815. (c) Jazzar, R. F. R.; Mahon, M. F.; Whittlesey, M. K. Organometallics 2001, 20, 3745. 
interested in examining the possibility to use a well-defined $\mathrm{Ru}(0)$ complex for modeling the challenging hydroacylation ${ }^{3,14-16}$ of an olefin or an alkyne with an aldehyde possessing a directing group in appropriate position along its aromatic or aliphatic chain, as elegantly achieved with rhodium by Willis et al. ${ }^{15}$ To our knowledge, Kondo and Mitsudo ${ }^{14 \mathrm{~d}}$ reported one of the rare examples of efficient Ru-catalyzed intermolecular hydroacylation of an olefin.

Roper's complex $\mathrm{Ru}(\mathrm{CO})_{2}\left(\mathrm{PPh}_{3}\right)_{3}(\mathbf{1}),{ }^{17}$ already known as one of the best precatalysts for the Murai reaction, ${ }^{2}$ might be $a$ priori regarded as a suitable candidate for that purpose, because of its high substitutional lability and well-established ability to activate $\mathrm{C}-\mathrm{H}$ and $\mathrm{C}-\mathrm{C}$ bonds. ${ }^{18} \mathrm{We}$ report here a clean stoichiometric sequence in which the latter complex is seen to achieve the intermolecular hydroacylation of an internal alkyne with a tethered aldehyde.

\section{Results and Discussion}

In the experimental model reaction presented here, 2-diphenylphosphanylbenzaldehyde ${ }^{19}$ was selected as a simple substrate possessing a phosphorus donor atom as strongly directing group susceptible of favoring a chelation-assisted hydroacylation. As shown in Scheme 1 (first equation), its reaction with $\mathbf{1}$ was found to proceed to completion at room temperature by the time of mixing the reactants, producing only one compound in good yield $(68 \%)$, with no detectable intermediate. Monitoring by infrared spectroscopy indicated that the carbonyl stretching vibrations of Roper's complex (1909 and $1857 \mathrm{~cm}^{-1}$ ) were shifted to 2024 and $1979 \mathrm{~cm}^{-1}$ during the course of the reaction,

(12) (a) Fabre, S.; Kalck, P.; Lavigne, G. Angew. Chem., Int. Ed. Engl. 1997, 36, 1092. (b) Lugan, N.; Lavigne, G.; Soulié, J. M.; Fabre, S.; Kalck, P.; Saillard, J.-Y.; Halet, J. F. Organometallics 1995, 14, 1713. (c) Lavigne, G.; Lugan, N.; Kalck, P.; Soulié, J. M.; Lerouge, O.; Saillard, J.-Y.; Halet, J. F. J. Am. Chem. Soc. 1992, 114, 10669.

(13) Ko, S.; Na, Y.; Chang, S. J. Am. Chem. Soc. 2002, 124, 750.

(14) For selected leading references on hydroacylation, see: (a) Marder, T. B.; Roe, C. D.; Milstein, D. Organometallics 1988, 7, 1451. (b) Lenges, C. P.; Brookhart, M. J. Am. Chem. Soc. 1997, 119, 3165. (c) Lenges, C. P.; White, P. S.; Brookhart, M. J. Am. Chem. Soc. 1998, 120, 6965. (d) Kondo, T.; Hiraishi, N.; Morisaki, Y.; Wada, K.; Watanabe, Y.; Mitsudo, T Organometallics 1998, 17, 2131.

(15) For recent leading references on chelation-controlled hydroacylation with rhodium, see: (a) Tanaka, M.; Imai, M.; Yamamoto, Y.; Tanaka, K.; Shimowatari, M.; Nagumo, S.; Kawahara, N.; Suemune, H. Org. Lett. 2003, 5, 1365. (b) Willis, M. C.; McNally, S. J.; Beswick, P. J. Angew. Chem., Int. Ed. 2004, 43, 340. (c) Willis, M. C.; Randell-Sly, H. E.; Woodward, R. L.; McNally, S. J.; Currie, G. S. J. Org. Chem. 2006, 71, 5291. (d) Moxham, G. L.; Randell-Sly, H. E.; Brayshaw, S. K.; Woodward, R. L.; Weller, A. S.; Willis, M. C. Angew. Chem., Int. Ed. 2006, 45, 7618.

(16) For recent leading references on the hydroacylation of olefins or alkynes in the presence of a chelation auxiliary, see: (a) Miura, M.; Nomura, M. J. Synth. Org. Chem. Jpn. 2000, 58, 578. (b) Jun, C. H.; Moon, C. W.; Lee, D.-Y. Chem.-Eur. J 2002, 8, 2423. (c) Jun, C.-H.; Lee, H.; Hong, J.-B.; Kwon, B.-I. Angew. Chem., Int. Ed. 2002, 41, 2146. (d) Lee, D.-Y.; Hong, B.-S.; Cho, E.-G.; Lee, H.; Jun, C.-H. J. Am. Chem. Soc. 2003, 125, 6372. (e) Kakiuchi, F.; Sato, T.; Tsujimoto, T.; Yamauchi, M.; Chatani, N.; Murai, S. Chem. Lett. 1998, 1053.

(17) Complex $\mathbf{1}$ is now readily available in high yield through a very simple procedure; see: Sentets, S.; Rodriguez Martinez, M.; Vendier, L.; Donnadieu, B.; Huc, V.; Lugan, N.; Lavigne, G. J. Am. Chem. Soc. 2005, 127, 14554.

(18) (a) Ogasawara, M.; Macgregor, S. A.; Streib, W. E.; Folting, K.; Eisenstein, O.; Caulton, K. G. J. Am. Chem. Soc. 1996, 118, 10189. (b) Alcock, N. W.; Hill, A. F.; Melling, R. P.; Thompsett, A. R. Organometallics 1993, 12, 641. (c) Dewhurst, R. D.; Hill, A. F.; M. K. Smith, Angew. Chem., Int. Ed. 2004, 43, 476. (d) Hill, A. F.; Rae, A. D.; Schultz, M.; Willis, A. C. Organometallics 2004, 23, 81. (e) Hill, A. F.; Schultz, M.; Willis, A. C. Organometallics 2004, 23, 5729. (f) Dewhurst, R. D.; Hill, A. F.; Smith, M. K. Organometallics 2005, 24, 6295. (g) Bartlett, M. J.; Hill, A. F.; Smith, M. L. Organometallics 2005, 24, 5795. (h) Dewhurst, R. D.; Hill, A. F.; Rae, A. D.; Willis, A. C. Organometallics 2005, 24, 3043.

(19) For a straightforward preparation of this ligand, see: Laue, S.; Greiner, L.; Wöltinger, J.; Liese, A. Adv. Synth. Catal. 2001, 343.
Scheme 1. Stepwise Reaction of 1 with 2-Diphenylphosphanylbenzaldehyde and Diphenylacetylene<smiles>C[R](C)(P(=O)(P)c1ccccc1)P(=O)(P)c1ccccc1</smiles>

(1)
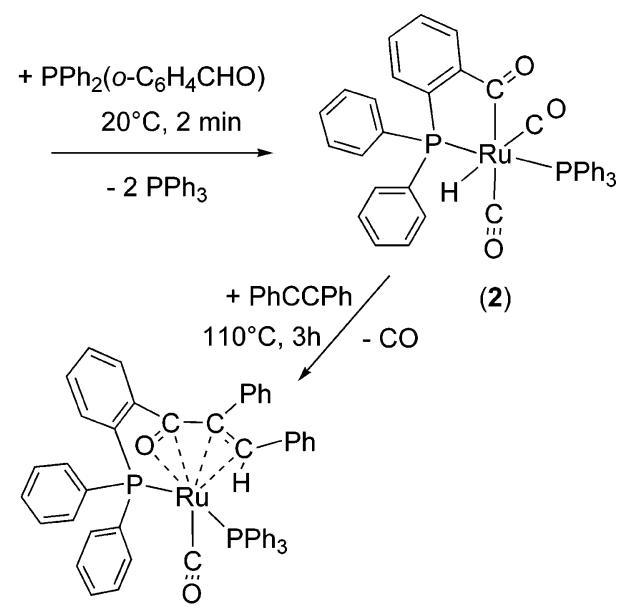

(3)
(2)
$78 \%$ yield

which is indicative of the formation of a $\mathrm{Ru}$ (II) complex. In ${ }^{1} \mathrm{H}$ NMR spectra, the appearance of a doublet of doublets at -5.81 ppm confirmed the presence of a hydrido ligand $\mathrm{Ru}-\mathrm{H}$ in connection with two distinct phosphine ligands. All analyses were consistent with the occurrence of a hydrido acyl $\mathrm{Ru}(\mathrm{II})$ species resulting from the oxidative addition of the $\mathrm{C}-\mathrm{H}$ bond of the aldehyde function to the metal, ${ }^{20,21}$ formulated as $\mathrm{Ru}(\mathrm{H})\left\{\mathrm{P}\left(\mathrm{C}_{6} \mathrm{H}_{5}\right)_{2}\left(\mathrm{C}_{6} \mathrm{H}_{4}\right) \mathrm{C}(\mathrm{O})\right\}(\mathrm{CO})_{2}\left(\mathrm{PPh}_{3}\right)(2)$.

To firmly confirm the structure, single crystals of $\mathbf{2}$ were grown by slow diffusion of pentane into a solution of $\mathbf{2}$ in $\mathrm{CH}_{2} \mathrm{Cl}_{2}$ and were submitted to an X-ray diffraction analysis. Crystal data are presented in Table 1 , whereas a perspective view of the molecule is shown in Figure 1. The complex is octahedral. Activation of the $\mathrm{C}-\mathrm{H}$ bond has produced the chelating phosphino acyl group " $\left(\mathrm{C}_{6} \mathrm{H}_{5}\right)_{2} \mathrm{P}\left(\mathrm{C}_{6} \mathrm{H}_{4}\right) \mathrm{C}(\mathrm{O})$ ", whereas the hydrido ligand is effectively seen to occupy a cis position relative to the acyl group. The two carbonyls are mutually cis, whereas the two phosphorus ligands are in trans position. NMR data confirm that this is the only isomer existing in solution. Let us note that an early observation by Rauchfuss ${ }^{20}$ that the reaction of $o$-(diphenylphosphino)benzaldehyde with $\mathrm{RuCl}_{3}$. $3 \mathrm{H}_{2} \mathrm{O}$ involves no $\mathrm{C}-\mathrm{H}$ bond activation had led the author to conclude that the reaction is "mechanistically different" from that observed with other platinum metals. ${ }^{20}$ In reality, what we see here is that the aptitude of the metal center to cleave such a bond depends on its oxidation state, which can also be inferred from related recent observations in the literature. ${ }^{21}$

Complex 2 was subsequently found to react cleanly with diphenylacetylene (Scheme 1, second equation). Here, the uptake of the alkyne was observed only under thermal activation, as required for the creation of a vacant coordination site. Gratifyingly, the position of the unique rising single $v(\mathrm{CO})$ absorption band at $1930 \mathrm{~cm}^{-1}$ for the final compound was consistent with the expected regeneration of a $\mathrm{Ru}(0)$ species. NMR data on this new compound indicated in particular that the hydride signal had disappeared and was replaced by a triplet at $\delta=2.74 \mathrm{ppm}$ $\left(J_{\mathrm{PH}}=7 \mathrm{~Hz}\right)$, which is characteristic for the proton signal of an olefin coordinated to a ruthenium $(0)$ center. The compound, identified as $\mathrm{Ru}\left\{\mathrm{P}\left(\mathrm{C}_{6} \mathrm{H}_{5}\right)_{2}\left(\mathrm{C}_{6} \mathrm{H}_{4}\right) \mathrm{C}(\mathrm{O})\left(\mathrm{C}_{6} \mathrm{H}_{5}\right) \mathrm{C}=\mathrm{CH}\left(\mathrm{C}_{6} \mathrm{H}_{5}\right)\right\}$ (CO) $\left\{\mathrm{P}\left(\mathrm{C}_{6} \mathrm{H}_{5}\right)_{3}\right\}$ (3), was isolated in $78 \%$ yield, whereas its

(20) Rauchfuss, T. B. J. Am. Chem. Soc. 1979, 101, 1045.

(21) Garralda, M. A.; Hernandez, R.; Ibarlucea, L.; Pinilla, E.; Torres, M. R.; Zarandona, M. Organometallics 2007, 26, 1031. 
Table 1. Crystal and Intensity Data for Complexes 2 and 3

\begin{tabular}{|c|c|c|}
\hline \multicolumn{3}{|c|}{ Crystal Data } \\
\hline formula & $\mathrm{C}_{39} \mathrm{H}_{30} \mathrm{O}_{3} \mathrm{P}_{2} \mathrm{Ru}, \mathrm{CH}_{2} \mathrm{Cl}_{2}$ & $\mathrm{C}_{52} \mathrm{H}_{40} \mathrm{O}_{2} \mathrm{P}_{2} \mathrm{Ru} \cdot 0.5\left(\mathrm{C}_{6} \mathrm{H}_{6}\right)$ \\
\hline fw & 794.57 & 898.90 \\
\hline cryst syst & monoclinic & monoclinic \\
\hline space group & $P 2_{1} / a($ No. 14$)$ & $C 2 / c$ (No. 15$)$ \\
\hline$a(\AA)$ & $20.0815(12)$ & $33.6265(15)$ \\
\hline$b(\AA)$ & $9.2617(5)$ & $12.5816(7)$ \\
\hline$c(\AA)$ & $20.7209(13)$ & $20.6793(10)$ \\
\hline$\alpha(\operatorname{deg})$ & 90.00 & 90.00 \\
\hline$\beta(\mathrm{deg})$ & $111.883(6)$ & $90.588(4)$ \\
\hline$\gamma(\mathrm{deg})$ & 90.00 & 90.00 \\
\hline$V\left[\AA^{3}\right]$ & $3576.2(4)$ & $8748.4(8)$ \\
\hline$Z$ & 4 & 8 \\
\hline$D($ calc $)\left(\mathrm{g} / \mathrm{cm}^{3}\right)$ & 1.476 & 1.365 \\
\hline$\mu(\mathrm{Mo} \mathrm{K} \alpha)\left(\mathrm{mm}^{-1}\right)$ & 0.715 & 0.474 \\
\hline$F(000)$ & 1616 & 3704 \\
\hline cryst size $(\mathrm{mm})$ & $0.30 \times 0.50 \times 0.50$ & $0.15 \times 0.20 \times 0.40$ \\
\hline \multicolumn{3}{|c|}{ Data Collection } \\
\hline temperature $(\mathrm{K})$ & 180 & 180 \\
\hline $\begin{array}{l}\text { radiation, } \\
\quad \text { Mo K } \alpha(\AA)\end{array}$ & 0.71073 & 0.71073 \\
\hline$\theta$ min., max. (deg) & $2.8,32.0$ & $3.1,32.1$ \\
\hline data set & $-29: 28 ;-11: 13 ;-30: 30$ & $-49: 49 ;-12: 18 ;-30: 30$ \\
\hline $\begin{array}{l}\text { total, unique no. } \\
\quad \text { of data, } R \text { (int) }\end{array}$ & $37012,11674,0.021$ & $46051,14337,0.065$ \\
\hline $\begin{array}{l}\text { no. of obsd data } \\
\quad(I>2.0 \sigma(I))\end{array}$ & 8618 & 7668 \\
\hline \multicolumn{3}{|c|}{ Refinement } \\
\hline$N_{\text {ref }}, N_{\text {par }}$ & 11674,451 & 14337,542 \\
\hline$R, w R^{2}, S^{a}$ & $0.0290,0.0752,1.09$ & $0.0525,0.1137,0.92$ \\
\hline $\begin{array}{l}\text { max. and av shift/ } \\
\text { error }\end{array}$ & $0.00,0.00$ & $0.00,0.00$ \\
\hline $\begin{array}{l}\text { min. and max. resd } \\
\text { dens }\left(e / \AA^{3}\right)\end{array}$ & $-0.54,0.83$ & $-0.98,1.33$ \\
\hline
\end{tabular}

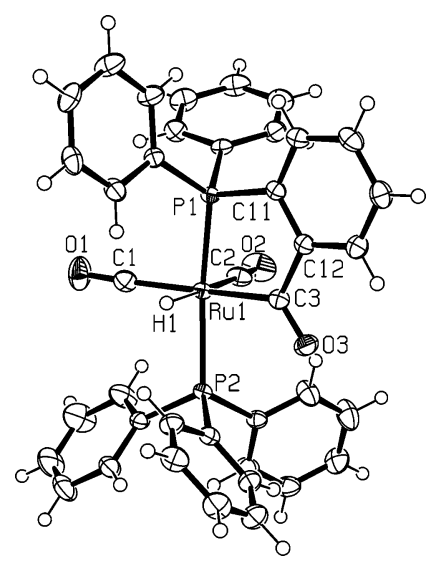

Figure 1. Molecular structure of the hydrido acyl complex 2 (thermal ellipsoids shown at the $30 \%$ probability level). Selected interatomic distances $(\AA)$ and angles (deg): $\mathrm{Ru}(1)-\mathrm{P}(1)$ 2.3092(4); $\mathrm{Ru}(1)-\mathrm{P}(2)$ 2.3773(4); $\mathrm{Ru}(1)-\mathrm{C}(1)$ 1.924(2); $\mathrm{Ru}(1)-\mathrm{C}(2)$ 1.936(2); $\mathrm{Ru}(1)-\mathrm{C}(3)$ 2.110(1); $\mathrm{C}(3)-\mathrm{O}(3)$ 1.225(2); $\mathrm{Ru}(1)-\mathrm{C}(3)-\mathrm{O}(3)$ 125.8(1); $\mathrm{P}(1)-\mathrm{Ru}(1)-\mathrm{C}(3)$ 82.32(3).

molecular structure was unambiguously established by X-ray diffraction. Crystal data are presented in Table 1, whereas a perspective view of the molecule is shown in Figure 2.

Clearly, the whole sequence observed here provides a realistic experimental model for the hydroacylation of diphenylacetylene with an aldehyde tethered onto a $\operatorname{Ru}(0)$ center. Whereas the presence of a directing group appears to be essential to trigger the activation of the $\mathrm{C}-\mathrm{H}$ bond of the aldehyde under very mild conditions, ${ }^{22}$ the vacant site required for further coordina-

(22) By contrast, with 2-bromobenzaldehyde, namely, in the absence of a better directing group than the oxygen of the acyl, we do observe "normal" activation at the ortho position, with competing cleavage of $\mathrm{C}-\mathrm{Br}$ and $\mathrm{C}-\mathrm{H}$ bonds (Benhamou, L.; Cesar, V.; Lugan, N.; Lavigne, G., in preparation).

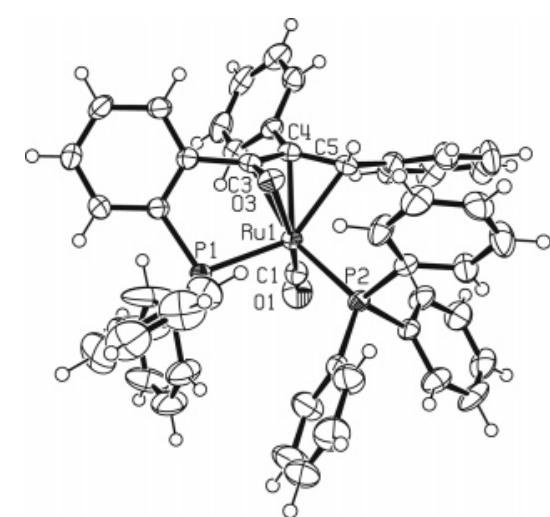

Figure 2. Molecular structure of complex 3 (thermal ellipsoids shown at the $30 \%$ probability level). Selected interatomic distances ( $): \mathrm{Ru}(1)-\mathrm{P}(1) 2.3398(8) ; \mathrm{Ru}(1)-\mathrm{P}(2)$ 2.3480(7); $\mathrm{Ru}(1)-\mathrm{C}(1)$ 1.824(3); $\mathrm{Ru}(1)-\mathrm{C}(3)$ 2.116(3); $\mathrm{Ru}(1)-\mathrm{O}(3)$ 2.158(2); $\mathrm{C}(3)-\mathrm{O}(3)$ 1.329(3); $\mathrm{Ru}(1)-\mathrm{C}(4)$ 2.202(3); $\mathrm{Ru}(1)-\mathrm{C}(5) 2.233(3) ; \mathrm{C}(4)-\mathrm{C}(5)$ 1.452(4); C(3)-C(4) 1.425(4); C(3)-C(12) 1.501(4).

tion of the alkyne is obtained by loss of one $\mathrm{CO}$ rather than loss of $\mathrm{PPh}_{3}$, in agreement with Morokuma's theoretical model of the Murai reaction, where the active species is proposed to be a monocarbonyl derivative. ${ }^{10}$ The subsequent transient elementary steps, namely, (i) insertion of the alkyne into the $\mathrm{Ru}-\mathrm{H}$ bond and (ii) reductive $\mathrm{CC}$ bond formation between the adjacent acyl and cis-stilbenyl groups, are seen to take place selectively without any undesirable side reaction. Very characteristically, the resulting newly assembled $\alpha, \beta$-unsaturated ketone moiety of the final (E)-1-(2-diphenylphosphino)phenyl)2,3-diphenylpropen-1-one ${ }^{23}$ ligand is bound to the metal in an $\eta^{4}$ coordination mode involving both a classical $\eta^{2}$ coordination of the olefinic bond and a rather uncommon "side-on" coordination of the $\mathrm{CO}$ bond. Although such a coordination mode has been already identified as a result of the complexation of preformed $\alpha, \beta$-unsaturated ketones, ${ }^{24}$ there is no precedent for its direct visualization as the effective $\mathrm{CC}$ bond forming step in the construction of such molecules. Interestingly, whereas the reductive elimination pathway observed here would normally create an unsaturation susceptible of allowing the complex to start another catalytic cycle, such a peculiar coordination mode reflects the tendency of the $\mathrm{Ru}(0)$ center to achieve a closedshell configuration while apparently awaiting a new incoming substrate.

At the present stage of our investigation, our attempts to transpose the reaction to the case of olefins such as styrene or triethoxyvinylsilane remained unsuccessful, probably due to the fact that olefins insert less easily than alkynes into a $\mathrm{Ru}-\mathrm{H}$ bond. Indeed, in such cases, we do observe the formation of $\mathrm{Ru}(\mathrm{CO})_{3}\left(\mathrm{PPh}_{3}\right)_{2}$ as a prevailing side reaction. This is understood as a decarbonylation of the acyl moiety of the cyclometalated ligand $\mathrm{Ph}_{2} \mathrm{P}\left(\mathrm{C}_{6} \mathrm{H}_{4}\right) \mathrm{C}(\mathrm{O})$ from 2 to give an elusive orthometalated intermediate, ${ }^{25}$ which ortho-demetalates by reductive coupling with the hydride to give a coordinated triphenylphosphine ligand.

(23) Although the hydroacylation on diphenylacetylene occurs as a formal syn addition, the CIP descriptor of the stilbenyl moiety is $E$ according to the priority rules.

(24) For selected examples of such a coordination mode with preformed $\alpha, \beta$-unsaturated ketones, see: (a) Graham, C. R.; Scholes, G.; Brookhart, M. J. Am. Chem. Soc. 1977, 99, 1180. (b) Zhang, W.-Y.; Jakiela, D. J.; Maul, A.; Knors, C.; Lauher, J. W.; Helquist, P.; Enders, D. J. Am. Chem. Soc. 1988, 110, 4652. (c) Hiraki, K.; Nonaka, A.; Matsunaga, T.; Kawano, H. J. Organomet. Chem. 1999, 574, 121.

(25) Bennet, M. A.; Clark, A. M.; Contel, M.; Rickard, C. E. F.; Roper, W. R.; Wright, L. J. J. Organomet. Chem. 2000, 601, 299. 
In the case of diphenylacetylene, we also attempted to perform the hydroacylation reaction in a catalytic way with either 2-ethoxybenzaldehyde (as a more synthetically useful aldehyde) or benzaldehyde (with the assistance of a chelation auxiliary such as 2-amino-3-methylpyridine), albeit with no success. Based on such observations, our future strategy in the quest for catalytically active species will require specific modifications of the metal's coordination sphere, in particular by incorporation of certain types of N-heterocyclic carbenes known to act as much better stabilizing ligands than triphenylphosphine.

\section{Experimental Section}

General Considerations. All manipulations were performed under an inert atmosphere of dry nitrogen by using standard vacuum line and Schlenk tube techniques. THF and diethyl ether were distilled from sodium/benzophenone and toluene was distilled from sodium. Pentane and dichloromethane were dried over $\mathrm{CaH}_{2}$ and subsequently distilled. Deuterated dichloromethane $\left(\mathrm{CD}_{2} \mathrm{Cl}_{2}\right)$ was dried over $\mathrm{CaH}_{2}$, vacuum distilled, degassed by three cycles of freeze-pump-thaw, and stored under nitrogen atmosphere in Teflon valve ampules. NMR spectra were recorded on Bruker AC200, AV300, or AV500 spectrometers. Infrared spectra were obtained as solutions on a Perkin-Elmer 1725 FT-IR spectrometer. Microanalyses were performed by the Laboratoire de Chimie de Coordination Microanalytical Service. 2-Diphenylphosphanylbenzaldehyde was prepared according to a literature procedure. ${ }^{19}$ Diphenylacetylene was purchased from Aldrich. $\mathrm{Ru}(\mathrm{CO})_{2}\left(\mathrm{PPh}_{3}\right)_{3}$ (1) ${ }^{17}$ was prepared using our new synthetic procedure from $\mathrm{Ru}(\mathrm{CO})_{3} \mathrm{Cl}_{2}$ (thf). ${ }^{26} \mathrm{RuCl}_{3} \cdot 3 \mathrm{H}_{2} \mathrm{O}$ was generously supplied by Johnson Matthey.

$\mathbf{R u}(\mathbf{H})\left\{\eta^{2}-\mathbf{P}\left(\mathbf{C}_{6} \mathbf{H}_{5}\right)_{2}\left(\mathbf{C}_{6} \mathbf{H}_{4} \mathbf{C O}\right)\right\}(\mathbf{C O})_{2}\left\{\mathbf{P}\left(\mathbf{C}_{6} \mathbf{H}_{5}\right)_{3}\right\}$ (2). A Schlenk tube equipped with a stir bar was charged with $\mathrm{Ru}(\mathrm{CO})_{2}\left(\mathrm{PPh}_{3}\right)_{3}$ (1) $(280 \mathrm{mg}, 0.30 \mathrm{mmol})$ and then with $20 \mathrm{~mL}$ of freshly distilled tetrahydrofuran. After complete dissolution, solid $\mathrm{P}\left(\mathrm{C}_{6} \mathrm{H}_{5}\right)_{2}\left(\mathrm{C}_{6} \mathrm{H}_{4}-\right.$ CHO) (100 mg, $0.35 \mathrm{mmol}$ ) was added all at once, which resulted in rapid disappearance of the initial yellow color. After 2-3 min, IR monitoring indicated the spectroscopically quantitative formation of a $\mathrm{Ru}$ (II) species. The solution was concentrated to one-fourth of its volume, and the new complex was precipitated upon addition of pentane. It was filtered with a filter paper tipped cannula, washed with pentane, dried, and weighed (145 mg, 68\% yield). Slow recrystallization from dichloromethane/pentane afforded pale yellow crystals of $\mathbf{2}$ directly suitable for the X-ray structure analysis.

IR ( $\left.v(\mathrm{CO}), \mathrm{THF}): 2024(\mathrm{~s}), 1979(\mathrm{vs}), v(\mathrm{C}=\mathrm{O})=1607(\mathrm{w}) \mathrm{cm}^{-1}\right)$. ${ }^{1} \mathrm{H}$ NMR $\left(200 \mathrm{MHz}, \mathrm{CD}_{2} \mathrm{Cl}_{2}, 293 \mathrm{~K}\right): \delta-5.81\left(\mathrm{dd},{ }^{2} J_{\mathrm{HP}}=17.5\right.$, $20.7 \mathrm{~Hz}, \mathrm{Ru}-H$,), 7.33-7.53 (m, 19H, $\left.\mathrm{CH}_{\text {arom }}\right), 7.67-7.75(\mathrm{~m}, 7 \mathrm{H}$, $\left.\mathrm{CH}_{\text {arom }}\right), 7.99-8.10\left(\mathrm{~m}, 3 \mathrm{H}, \mathrm{C} H_{\text {arom }}\right) \mathrm{ppm} .{ }^{13} \mathrm{C}\left\{{ }^{1} \mathrm{H}\right\} \mathrm{NMR}(75.5$ $\left.\mathrm{MHz}, \mathrm{CD}_{2} \mathrm{Cl}_{2}, 293 \mathrm{~K}\right): \delta 258.4\left(\mathrm{dd},{ }^{2} J_{\mathrm{CP}}=6.5,8.2 \mathrm{~Hz}, C=\mathrm{O}\right), 200.6$ $\left(\mathrm{t},{ }^{2} J_{\mathrm{CP}}=8.6 \mathrm{~Hz}, C \mathrm{O}\right), 198.5\left(\mathrm{t},{ }^{2} J_{\mathrm{CP}}=8.1 \mathrm{~Hz}, C \mathrm{O}\right), 157.8\left(\mathrm{~d}, J_{\mathrm{CP}}\right.$ $\left.=41.0 \mathrm{~Hz}, \mathrm{Ph}_{2} \mathrm{P}-\mathrm{C}\left(\mathrm{C}_{6} \mathrm{H}_{4} \mathrm{CO}\right)\right), 139.3\left(\mathrm{~d}, J_{\mathrm{CP}}=45.3 \mathrm{~Hz}\right), 137.2$ $\left(\mathrm{d}, J_{\mathrm{CP}}=45.1 \mathrm{~Hz}\right), 136.2\left(\mathrm{dd}, J_{\mathrm{CP}}=43.0,1.3 \mathrm{~Hz}\right), 133.9\left(\mathrm{~d}, J_{\mathrm{CP}}\right.$

(26) Faure, M.; Maurette, L.; Donnadieu, B.; Lavigne, G. Angew. Chem., Int. Ed. 1999, 38, 518.
$=11.0 \mathrm{~Hz}), 133.8\left(\mathrm{~d}, J_{\mathrm{CP}}=11.3 \mathrm{~Hz}\right), 131.4\left(\mathrm{~d}, J_{\mathrm{CP}}=11.3 \mathrm{~Hz}\right)$, $130.9\left(\mathrm{~d}, J_{\mathrm{CP}}=2.8 \mathrm{~Hz}\right), 130.7($ br s $), 130.5\left(\mathrm{~d}, J_{\mathrm{CP}}=6.0 \mathrm{~Hz}\right)$, $129.8\left(\mathrm{~d}, J_{\mathrm{CP}}=2.3 \mathrm{~Hz}\right), 129.6\left(\mathrm{~d}, J_{\mathrm{CP}}=2.8 \mathrm{~Hz}\right), 128.5\left(\mathrm{~d}, J_{\mathrm{CP}}=\right.$ $10.2 \mathrm{~Hz}), 127.2\left(\mathrm{~d}, J_{\mathrm{CP}}=9.8 \mathrm{~Hz}\right), 120.6\left(\mathrm{~d}, J_{\mathrm{CP}}=16.8 \mathrm{~Hz}\right.$, $\left.o-C\left(\mathrm{C}_{6} \mathrm{H}_{4} \mathrm{CO}\right)\right)$ ppm. ${ }^{31} \mathrm{P}\left\{{ }^{1} \mathrm{H}\right\}$ NMR $\left(81.015 \mathrm{MHz}, \mathrm{CD}_{2} \mathrm{Cl}_{2}, 293\right.$ $\mathrm{K}): \delta 75.6\left(\mathrm{~d},{ }^{2} J_{\mathrm{PP}}=213 \mathrm{~Hz}, P \mathrm{Ph}_{2},\right), 49.2\left(\mathrm{~d},{ }^{2} J_{\mathrm{PP}}=213 \mathrm{~Hz}\right.$, $\left.\mathrm{PPh}_{3}\right)$ ppm. MS (FAB, MNBA): $m / z(\%) 682(12)[\mathrm{M}-\mathrm{CO}]$, 654 (29) [M - 2CO], $626(47)\left[\mathrm{RuC}_{36} \mathrm{H}_{30} \mathrm{P}_{2}\right], 363$ (100) $\left[\mathrm{Ru}\left(\mathrm{PPh}_{3}\right)\right]$. Anal. Calcd (\%) for $\mathrm{C}_{39} \mathrm{H}_{30} \mathrm{O}_{3} \mathrm{P}_{2} \mathrm{Ru}$ (709.67): C 66.00, $\mathrm{H} 4.26$. Found: C 65.10, $\mathrm{H} 4.00$.

$\mathbf{R u}\left\{\eta^{5}-\mathbf{P}\left(\mathrm{C}_{6} \mathrm{H}_{5}\right)_{2}\left(\mathrm{C}_{6} \mathrm{H}_{4} \mathrm{CO}-\mathrm{C}\left(\mathrm{C}_{6} \mathrm{H}_{5}\right) \mathrm{CH}\left(\mathrm{C}_{6} \mathrm{H}_{5}\right)\right)\right\}(\mathrm{CO})\left\{\mathbf{P}\left(\mathrm{C}_{6^{-}}\right.\right.$ $\left.\left.\mathbf{H}_{5}\right)_{3}\right\}$ (3). Complex 2 (90 mg, $0.13 \mathrm{mmol}$ ) and diphenylacetylene (27 mg, $0.15 \mathrm{mmol}$ ) were dissolved in $10 \mathrm{~mL}$ of toluene in a Schlenk flask connected with a reflux condenser. The solution was heated at $110{ }^{\circ} \mathrm{C}$ for $3 \mathrm{~h}$, cooled to room temperature, and concentrated under vacuum. The resulting complex was precipitated with pentane and was then filtered, washed with pentane, and weighed ( $78 \%$ yield). Slow diffusion of pentane into a concentrated solution of $\mathbf{3}$ in benzene gave suitable crystals for the X-ray structure analysis. ${ }^{22}$

IR ( $v(\mathrm{CO}), \mathrm{THF}): 1931(\mathrm{vs}) \mathrm{cm}^{-1} \cdot{ }^{1} \mathrm{H}$ NMR $\left(500 \mathrm{MHz}, \mathrm{CD}_{2-}\right.$ $\left.\mathrm{Cl}_{2}, 293 \mathrm{~K}\right): \delta 2.74\left(\mathrm{t}, 1 \mathrm{H}, J_{\mathrm{HP}}=7.0 \mathrm{~Hz}, \mathrm{C}=\mathrm{CH}\right), 6.53(\mathrm{~d}, 2 \mathrm{H}$, $\left.J_{\mathrm{HH}}=5.0 \mathrm{~Hz}, \mathrm{C} H_{\text {arom }}\right), 6.85-6.98\left(\mathrm{~m}, 5 \mathrm{H}, \mathrm{C} H_{\text {arom }}\right), 7.13-7.31$ (m, 28H, $\left.\mathrm{CH}_{\text {arom }}\right), 7.44-7.48\left(\mathrm{~m}, 4 \mathrm{H}, \mathrm{CH}_{\text {arom }}\right) \mathrm{ppm} .{ }^{13} \mathrm{C}\left\{{ }^{1} \mathrm{H}\right\} \mathrm{NMR}$ $\left(125.8 \mathrm{MHz}, \mathrm{CD}_{2} \mathrm{Cl}_{2}, 293 \mathrm{~K}\right): \delta 206.0\left(\mathrm{t}, \mathrm{Ru}-\mathrm{CO}, J_{\mathrm{CP}}=12.6 \mathrm{~Hz}\right)$, $148.5\left(\mathrm{dd}, J_{\mathrm{CP}}=40.3,6.3 \mathrm{~Hz}, C \mathrm{O}_{\text {enone }}\right), 145.8\left(\mathrm{~d}, J_{\mathrm{CP}}=21.4 \mathrm{~Hz}\right)$, $143.3\left(\mathrm{~d}, J_{\mathrm{CP}}=3.8 \mathrm{~Hz}\right), 138.3(\mathrm{~m}), 136.4(\mathrm{~s}), 135.8\left(\mathrm{~d}, J_{\mathrm{CP}}=40.3\right.$ $\mathrm{Hz}), 134.6\left(\mathrm{~d}, J_{\mathrm{CP}}=28.9 \mathrm{~Hz}\right), 134.2(\mathrm{~s}), 133.3\left(\mathrm{~d}, J_{\mathrm{CP}}=11.3 \mathrm{~Hz}\right)$, $132.1\left(\mathrm{~d}, J_{\mathrm{CP}}=11.3 \mathrm{~Hz}\right), 131.8\left(\mathrm{~d}, J_{\mathrm{CP}}=10.1 \mathrm{~Hz}\right), 129.9\left(\mathrm{~d}, J_{\mathrm{CP}}\right.$ $=1.3 \mathrm{~Hz}), 129.5\left(\mathrm{~d}, J_{\mathrm{CP}}=1.3 \mathrm{~Hz}\right), 129.2\left(\mathrm{~d}, J_{\mathrm{CP}}=1.3 \mathrm{~Hz}\right), 128.7$ $\left(\mathrm{d}, J_{\mathrm{CP}}=1.3 \mathrm{~Hz}\right), 128.4\left(\mathrm{~d}, J_{\mathrm{CP}}=10.1 \mathrm{~Hz}\right), 127.9(\mathrm{~s}), 127.8(\mathrm{~d}$, $\left.J_{\mathrm{CP}}=10.1 \mathrm{~Hz}\right), 127.7(\mathrm{~s}), 127.4(\mathrm{~s}), 126.5(\mathrm{~s}), 123.4(\mathrm{~s}) ; 106.9(\mathrm{t}$, $\left.J_{\mathrm{CP}}=3.8 \mathrm{~Hz},=C(\mathrm{Ph})(\mathrm{COR})\right), 55.3\left(\mathrm{~d}, J_{\mathrm{CP}}=28.9 \mathrm{~Hz},=C \mathrm{H}\right) \mathrm{ppm}$. ${ }^{31} \mathrm{P}\left\{{ }^{1} \mathrm{H}\right\}$ NMR $\left(202.5 \mathrm{MHz}, \mathrm{CD}_{2} \mathrm{Cl}_{2}, 293 \mathrm{~K}\right): \delta 46.9\left(\mathrm{~s}, \mathrm{PPh}_{3}\right)$, 30.9 (s, $\left.\mathrm{PPh}_{2}-\mathrm{C}_{6} \mathrm{H}_{4} \mathrm{CO}\right)$ ppm. MS (FAB, MNBA): $\mathrm{m} / \mathrm{z}(\%) 860$ (30) $[\mathrm{M}], 831$ (3) [M - CO], 570 (42) [M - CO - $\left.\mathrm{PPh}_{3}\right], 542$ (91) $\left[\mathrm{RuC}_{32} \mathrm{H}_{25} \mathrm{P}\right], 362(100)\left[\mathrm{Ru}\left(\mathrm{PPh}_{3}\right)\right]$. Anal. Calcd $(\%)$ for $\mathrm{C}_{52} \mathrm{H}_{40} \mathrm{O}_{2} \mathrm{P}_{2} \mathrm{Ru}$ (859.89): C 72.63, H 4.69. Found: C 72.44, H 4.67.

Crystal Structure Analyses. Crystal and intensity data for 2 and 3 were collected on an Oxford Diffraction XCALIBUR diffractometer equipped with a low-temperature device. Crystal and intensity data are listed in Table 1. Perspective views of these two complexes are shown in Figures 1 and 2, respectively, along with a selection of the main interatomic distances and bond angles. A full listing of crystallographic data is available in the CIF files provided as Supporting Information.

Acknowledgment. The authors thank the CNRS for financial support and Johnson Matthey for generous gifts of $\mathrm{RuCl}_{3} \cdot n \mathrm{H}_{2} \mathrm{O}$.

Supporting Information Available: CIF files giving crystallographic data and including a full list of interatomic bond lengths and angles for compounds $\mathbf{2}$ and $\mathbf{3}$. This material is available free of charge via the Internet at http://pubs.acs.org.

\section{OM7005003}

